\title{
Teaching Video NeuroImages: Infratentorial Multiple Sclerosis Relapse Presenting as Continuous Hemifacial Myokymia
}

Manuel Salavisa, MD, Filipa Serrazina, MD, Pedro Pires, MD, and Ana Sofia Correia, MD

Neurology ${ }^{\circledR} 2021 ; 97:$ e111-e112. doi:10.1212/WNL.0000000000012052

Figure MRI Findings

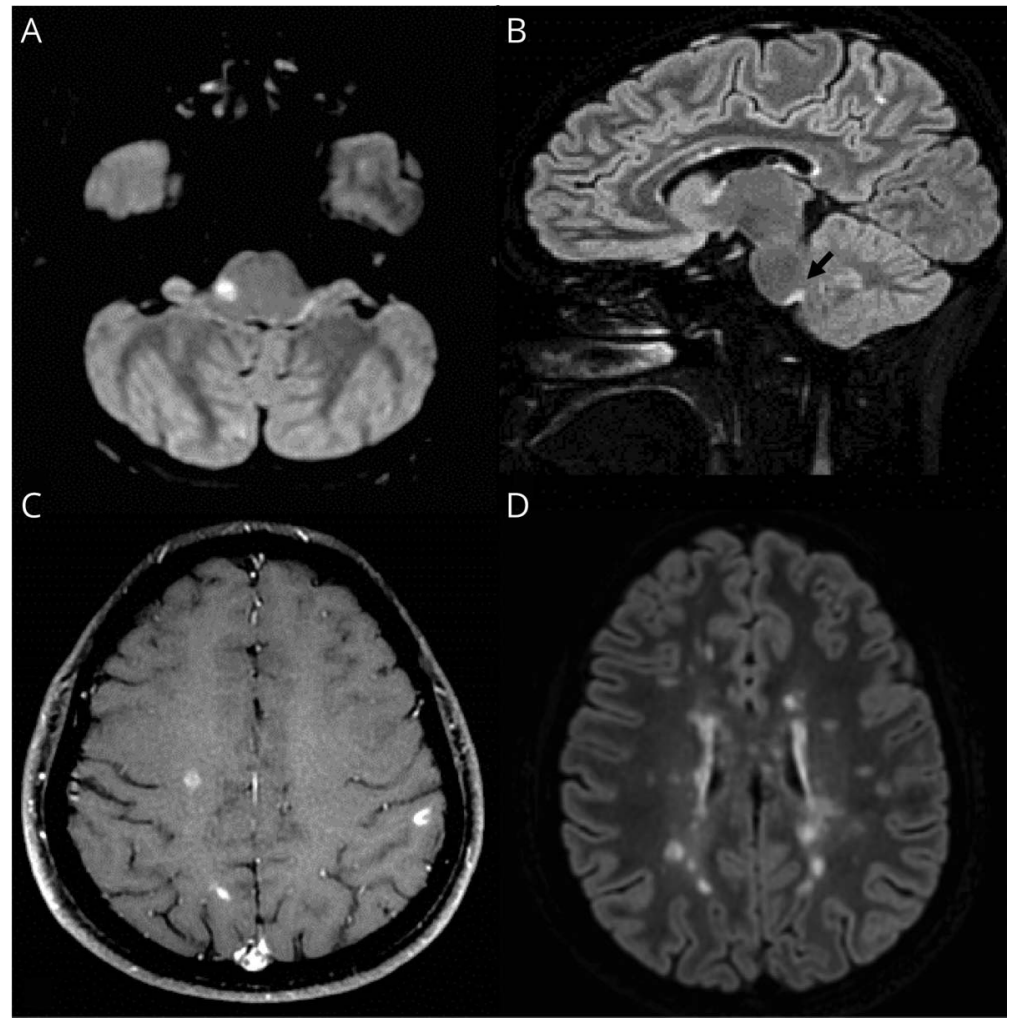

(A) Axial/(B) sagittal MRI brain T2-weighted fluid-attenuated inversion recovery (FLAIR) images show a hyperintense lesion on the right dorsolateral pons, with local swelling, lying near the facial nerve nucleus, and involving the bulbopontine sulcus (arrow). (C) Axial T1 after gadolinium/(D) T2 FLAIR images reveal typical demyelinating supratentorial lesions.

A 26-year-old woman with an 8-year history of untreated multiple sclerosis (MS) presented with acute-onset continuous involuntary wavelike movements on the right side of her face (video). Neurologic examination revealed continuous right-sided hemifacial myokymia (CFM), with no concurrent hemifacial spasm. MRI documented a new nonenhancing lesion in the dorsolateral right pontine tegmentum and multiple supratentorial demyelinating lesions (figure, A-D). Symptoms spontaneously resolved 3 weeks later. MS relapses may involve the postnuclear facial nerve course within the pontine tegmentum,

\section{Correspondence}

Dr. Salavisa

mteixeira1@campus.ul.pt
MORE ONLINE

O Video

$\rightarrow$ Teaching slides

http://links.lww.com/

$\mathrm{WNL} / \mathrm{B} 373$ 
producing ipsilateral CFM. ${ }^{1,2}$ Strict unilaterality and perioral involvement argue against benign eyelid myokymia and should suggest a structural pontic lesion, warranting neuroimaging.

\section{Acknowledgment}

The authors thank the patient for allowing her case to be shared.

\section{Study Funding}

No targeted funding reported.

\section{Disclosure}

M. Salavisa has received support for scientific meetings from Sanofi Genzyme, Roche, and Merck Serono. F. Serrazina has received support for scientific meetings from Roche and Sanofi Genzyme. P. Pires reports no disclosures relevant to the manuscript. A.S. Correia participates as an investigator in clinical trials and observational studies sponsored by Biogen, Merck, Novartis, and SanofiGenzyme; received an educational sponsorship from Merck Serono; and received personal compensation for participating on advisory boards from Novartis, Biogen, Sanofi-Genzyme, Merck, and Roche, and for participating as a speaker at meetings and teaching courses sponsored by Biogen and Novartis. Go to Neurology.org/N for full disclosures.

\section{Appendix Authors}

\begin{tabular}{|c|c|c|}
\hline Name & Location & Contribution \\
\hline $\begin{array}{l}\text { Manuel } \\
\text { Salavisa, } \\
\text { MD }\end{array}$ & $\begin{array}{l}\text { Department of Neurology, } \\
\text { Hospital Egas Moniz, Centro } \\
\text { Hospitalar Lisboa Ocidental, } \\
\text { Portugal }\end{array}$ & $\begin{array}{l}\text { Drafting/revision of the } \\
\text { manuscript for content, } \\
\text { including medical writing for } \\
\text { content; major role in the } \\
\text { acquisition of data; study } \\
\text { concept or design; analysis or } \\
\text { interpretation of data }\end{array}$ \\
\hline $\begin{array}{l}\text { Filipa } \\
\text { Serrazina, } \\
\text { MD }\end{array}$ & $\begin{array}{l}\text { Department of Neurology, } \\
\text { Hospital Egas Moniz, Centro } \\
\text { Hospitalar Lisboa Ocidental, } \\
\text { Portugal }\end{array}$ & $\begin{array}{l}\text { Drafting/revision of the } \\
\text { manuscript for content, } \\
\text { including medical writing for } \\
\text { content; study concept or } \\
\text { design; analysis or } \\
\text { interpretation of data }\end{array}$ \\
\hline $\begin{array}{l}\text { Pedro } \\
\text { Pires, MD }\end{array}$ & $\begin{array}{l}\text { Department of } \\
\text { Neuroradiology, Hospital } \\
\text { Egas Moniz, Centro } \\
\text { Hospitalar Lisboa Ocidental, } \\
\text { Portugal }\end{array}$ & $\begin{array}{l}\text { Drafting/revision of the } \\
\text { manuscript for content, } \\
\text { including medical writing for } \\
\text { content; major role in the } \\
\text { acquisition of data; analysis or } \\
\text { interpretation of data }\end{array}$ \\
\hline $\begin{array}{l}\text { Ana Sofia } \\
\text { Correia, } \\
\text { MD }\end{array}$ & $\begin{array}{l}\text { CEDOC-NOVA Medical } \\
\text { School, Universidade Nova de } \\
\text { Lisboa, Portugal }\end{array}$ & $\begin{array}{l}\text { Drafting/revision of the } \\
\text { manuscript for content, } \\
\text { including medical writing for } \\
\text { content; analysis or } \\
\text { interpretation of data }\end{array}$ \\
\hline
\end{tabular}

\section{References}

1. Marin Collazo I, Tobin W. Facial myokymia and hemifacial spasm in multiple sclerosis: a descriptive study on clinical features and treatment outcomes. Neurologist 2018;23(1):1-6.

2. Jacobs L, Kaba S, Pullicino P. The lesion causing continuous facial myokymia in multiple sclerosis. Arch Neurol 1994;51(11):1115-1119. 


\section{Neurology}

\section{Teaching Video NeuroImages: Infratentorial Multiple Sclerosis Relapse Presenting as Continuous Hemifacial Myokymia}

Manuel Salavisa, Filipa Serrazina, Pedro Pires, et al.

Neurology 2021;97;e111-e112 Published Online before print April 26, 2021

DOI 10.1212/WNL.0000000000012052

\section{This information is current as of April 26, 2021}

Updated Information \& Services

References

Subspecialty Collections

Permissions \& Licensing

Reprints including high resolution figures, can be found at: http://n.neurology.org/content/97/1/e111.full

This article cites 2 articles, 0 of which you can access for free at: http://n.neurology.org/content/97/1/e111.full\#ref-list-1

This article, along with others on similar topics, appears in the following collection(s):

Clinical neurology examination

http://n.neurology.org/cgi/collection/clinical_neurology_examination Multiple sclerosis

http://n.neurology.org/cgi/collection/multiple_sclerosis

Information about reproducing this article in parts (figures,tables) or in its entirety can be found online at:

http://www.neurology.org/about/about_the_journal\#permissions

Information about ordering reprints can be found online:

http://n.neurology.org/subscribers/advertise

Neurology ${ }^{\circledR}$ is the official journal of the American Academy of Neurology. Published continuously since 1951, it is now a weekly with 48 issues per year. Copyright @ 2021 American Academy of Neurology. All rights reserved. Print ISSN: 0028-3878. Online ISSN: 1526-632X.

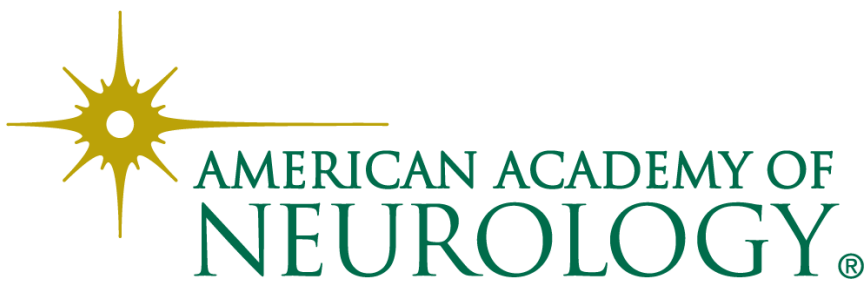

